\title{
Inhibition of Yellowing and Ethylene Production in Broccoli Florets following High Temperature Treatment with Hot Air
}

\author{
TERAI Hirofumi*, KANOU Maki*, MizUnO Masashi** \\ and TSUCHIDA Hironobu* \\ * Faculty of Agriculture, Kobe University \\ 1-1 Rokkodai-cho Nada-ku, Kobe 657-8501 \\ * * Graduate School of Science and Technology, Kobe University \\ 1-1 Rokkodai-cho Nada-ku, Kobe 657-8501
}

\begin{abstract}
High temperature treatment (HTT) with hot air at 45,50 or $55^{\circ} \mathrm{C}$ for 1 to $5 \mathrm{hr}$ prior to storage at $20^{\circ} \mathrm{C}$ was conducted to delay the yellowing of harvested broccoli florets. $\mathrm{HTT}$ at $50^{\circ} \mathrm{C}$ for 2 and $3 \mathrm{hr}$ were more effective than others for maintaining green color and good quality of broccoli florets. Loss of chlorophyl and increase of carbon dioxide and ethylene production in the florets during storage at $20^{\circ} \mathrm{C}$ were inhibited by HTT at $50^{\circ} \mathrm{C}$ for 1,2 and $3 \mathrm{hr}$ except for the chlorophyll loss of $1 \mathrm{hr}$ treatment. Inhibitions rates increased with in duration of HTT. 1aminocyclopropane-1-carboxylic acid (ACC) content in florets during storage increased with the same rates in the control and $\mathrm{HTT}$ at $50^{\circ} \mathrm{C}$ for 1 and $2 \mathrm{hr}$, but the HTT for $3 \mathrm{hr}$ retarded the increase in ACC content. Activity of ACC oxidase in the florets during storage increased remarkably in the control and HTT at $50^{\circ} \mathrm{C}$ for $1 \mathrm{hr}$, followed by those with the HTT for $2 \mathrm{hr}$, which reached maxima and subsequently declined quickly to low levels. However, in the florets with $\mathrm{HTT}$ at $50^{\circ} \mathrm{C}$ for $3 \mathrm{hr}$, scarcely any enzyme activity was detected during storage. These results suggest that $\mathrm{HTT}$ at $50^{\circ} \mathrm{C}$ for a short-term period would inhibit the conversion of ACC to ethylene and reduce ethylene production resulting in the retardation of yellowing in broccoli florets.
\end{abstract}

(Received Jan. 21, 1999 ; Accepted Jul. 19, 1999)

To maintain good quality of harvested fruits and vegetables over a long time, it is best to store these crops at low temperature preventing them from chilling injury. However, OGURA et al. ${ }^{1)}$ found that tomato fruit which were harvested at mature green stage and treated at $33^{\circ} \mathrm{C}$ for 10 to 20 days could be stored for 4 to 7 months at room temperature. Subsequently, many reports ${ }^{2) ~}-9$ ) showed that high temperature treatment (HTT) at $30{ }^{\circ} \mathrm{C}$ or above contributed to the inhibition of ripening in some cases but not in others. In these reports, PORRITT and LIDSTER ${ }^{5)}$ pointed out that softening of apples exposed to $38^{\circ} \mathrm{C}$ for 4 to 6 days could be prevented during subsequent storage at $-1^{\circ} \mathrm{C}$, and Komiyama et $a l .^{7)}$ and Tsuji et al. ${ }^{8)}$ found that high temperature storage at $30^{\circ} \mathrm{C}$ was effective to keep qualities in 'Sordum' plums. In many of these reports, it has been suggested that HTT would inhibit ethylene production in fruits.

It has also been reported that proper hot water treatment was effective in maintaining the green color of broccoli florets during subsequent storage 10) 13 ). However, it is feared that hot water treatment would sometimes damage the quality due to excessive moisture content during storage. With respect to HTT with hot air for a short-term period without resort to hot water, therefore, we carried out the present sutdy to clarify the optimum temperature and duration of HTT for inhibition of yellowing and maintenance of good 
quality in broccoli florets. Moreover, to examine the effects of HTT on the ethylene biosynthetic pathway, changes in $\mathrm{ACC}$ content and $\mathrm{ACC}$ oxidase activity were monitored during storage after various durations of treatment.

\section{Materials and Methods}

\section{Materials}

Fresh broccoli (Brassica oleracea L.) heads imported from the USA were used in this study.

\section{High temperature treatment}

HTT was conducted by holding the broccoli heads in incubators at 45,50 or $55^{\circ} \mathrm{C}$ for 0 (control), $1,2,3$ or $5 \mathrm{hr}$ followed by storage at $20^{\circ} \mathrm{C}$. During the treatment, the broccoli heads were covered with perforated polyethylene bags $(23 \mathrm{~cm} \times 35 \mathrm{~cm}$ with eight $\phi 5 \mathrm{~mm}$ holes on each side) loosely to reduce the weight loss. After treatment, the broccoli heads were stored at $20^{\circ} \mathrm{C}$ in the perforated polyethylene bags until being zed.

\section{Determination of organoleptic color score}

The color score in broccoli florets was evaluated visually according to the percentage of the yellowed area and color tone on the head from 0 to 5 scale, $0=0 \%$ yellowing, $0.5=$ below $5 \%, 1=10 \%$, $1.5=20-30 \%, 2=40-60 \%, 2.5=70-90 \%, 3=100 \%$ (light yellow), $4=$ dark yellow and $5=$ brown.

\section{Assay of chlorophyll}

Measurement of chlorophyll content was based on the method of INSKEEP and BLOOM ${ }^{14)}$. Four $g$ of florets excised from whole heads were immersed in $50 \mathrm{~m} \ell$ of $N, N$-dimethylformamide and stored at $5{ }^{\circ} \mathrm{C}$ in the dark for $24 \mathrm{hr}$. Chlorophyll was assayed by reading the absorbance of the solvent at $647 \mathrm{~nm}$ and $664.5 \mathrm{~nm}$. Total chlorophyll content was calculated by the sum of chlorophyll $\mathrm{a}$ and $\mathrm{b}$.

\section{Assay of carbon dioxide and ethylene production}

To determine the carbon dioxide and ethylene production, ca. $40 \mathrm{~g}$ of florets separated from whole heads were placed in a $840 \mathrm{~m} \ell$ container. The container was sealed for $2 \mathrm{hr}$ at $20^{\circ} \mathrm{C}$ and the head space gas was withdrawn with a syringe. Carbon dioxide and ethylene concentrations were determined with TCD and FID gas chromatographs, respectively, which were fitted with Porapak $Q$ columns.

\section{Extraction and assay of 1-aminocyclopropane-} 1-carboxylic acid (ACC)

ACC was extracted from florets with $80 \%$ ethanol and assayed as described in the previous report ${ }^{15)}$, which slightly modified the method of LIZADA and YANG ${ }^{16)}$.

\section{Extraction and assay of $A C C$ oxidase}

The extraction and assay of ACC oxidase were based on the methods described by VERVERIDIS and JOHN ${ }^{17)}$ and HYODO et al. ${ }^{18)}$ with slight modifications. Florets were homogenized in liquid nitrogen with a mortar and pestle, and $4 \mathrm{~g}$ of frozen powdered tissue were suspended in $20 \mathrm{~m} \ell$ of $0.1 \mathrm{M}$ Tris- $\mathrm{HCl}$ buffer ( $\mathrm{pH} 7.2$ ) containing 30\% $(\mathrm{w} / \mathrm{v})$ glycerol and $10 \mathrm{mM}$ sodium ascorbate. The homogenate was centrifuged at $20,000 \times \mathrm{g}$ for 20 min, and the supernatant was saved as crude extract. The ACC oxidase reaction was carried out in a $29 \mathrm{~m} \ell$ test tube with a rubber stopper containing $0.5 \mathrm{~m} \ell$ of crude extract, $0.2 \mathrm{~m} \ell$ of $10 \mathrm{mM}$ ACC, $0.2 \mathrm{~m} \ell$ of $100 \mathrm{mM}$ sodium ascorbate, $0.2 \mathrm{~m} \ell$ of $500 \mu \mathrm{M} \mathrm{FeSO}_{4}, 0.1 \mathrm{~m} \ell$ of $200 \mathrm{mM} \mathrm{NaHCO}{ }_{3}$ and 0.8 $\mathrm{m} \ell$ of $0.1 \mathrm{M}$ Tris- $\mathrm{HCl}$ buffer ( $\mathrm{pH} 7.2,30 \%$ glycerol). After incubation for 1 and $2 \mathrm{hr}$ at $30^{\circ} \mathrm{C}$, a $1 \mathrm{~m} \ell$ of head space gas was withdrawn with a syringe, and ethylene was analyzed by FID gas chromatography.

\section{Calculations}

Carbon dioxide and ethylene production rates, chlorophyll and ACC contents, and ACC oxidase activity were expressed per weight of fresh matters of florets prior to HTT. In all figures, the standard errors calculated with three or four replications were represented as vertical bars.

\section{Results and Discussion}

Broccoli heads treated at high temperatures of 45,50 or $55^{\circ} \mathrm{C}$ for 1 to $5 \mathrm{hr}$ were monitored to determine the effect of HTT on retardation of yellowing of the heads during subsequent storage (Fig. 1-A, $-\mathrm{B}$ and $-\mathrm{C}$ ). In the heads treated at $45^{\circ} \mathrm{C}$ (A), the yellowing proceeded regardless of the duration of treatment. However, no yellowing was 

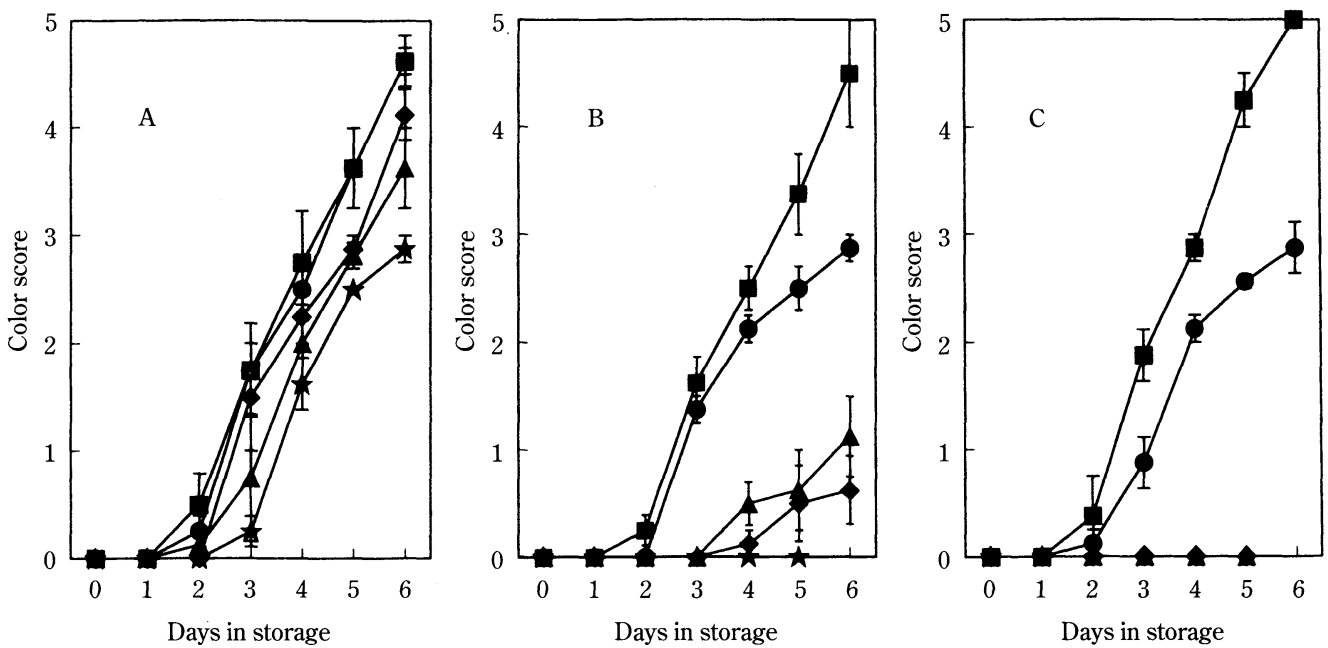

Fig. 1 Changes in organoleptic color score of broccoli florets during storage at $20^{\circ} \mathrm{C}$ The broccoli heads were treated at 45 (A), 50 (B) or $55^{\circ} \mathrm{C}$ (C) for $0(\mathbf{\square}), 1(\boldsymbol{\bullet}), 2(\mathbf{\Delta}), 3(\boldsymbol{\bullet})$ or $5 \mathrm{hr}(\star)$ and subsequently, packed in perforated polyethylene bags and stored at $20^{\circ} \mathrm{C}$. The color score in florets ; $0=0 \%$ yellowing, $0.5=$ below $5 \%, 1=10 \%, 1.5=20-30 \%, 2=40-60 \%, 2.5=70-90 \%, 3=100 \%$ (light yellow), $4=$ dark yellow, and $5=$ brown

observed during storage but decay started on day 2 of storage in the heads treated at $55^{\circ} \mathrm{C}$ (C) for 2 , 3 and $5 \mathrm{hr}$. Yellowing of the broccoli heads treated at $50{ }^{\circ} \mathrm{C}$ ( B ) for $2 \mathrm{hr}$ or more was remarkably retarded during storage but in the heads treated for $5 \mathrm{hr}$, the decay started on day 2 of storage. Consequently, the florets treated for 2 and $3 \mathrm{hr}$ maintained good quality for a longer time than others. FORNEY ${ }^{11}$ ) reported that in pretreatment with hot water before storage of broccoli florets, the treatment at $50^{\circ} \mathrm{C}$ for $2 \mathrm{~min}$ was most effective in preventing yellowing and decay, but treatment at $52{ }^{\circ} \mathrm{C}$ promoted the development of off-odor. Although the hot air treatment adopted in the present study the required a longer period than the hot water treatment until the a rise of designated temperature, $50^{\circ} \mathrm{C}$ in both treatments brought favorable effects, but slight differences in temperature for treatment undermined those effects. These results suggest that the physiological activities of broccoli would vary within a considerably narrow temperature range. Based on these facts, the HTT in the subsequent experiments was performed at $50^{\circ} \mathrm{C}$.

Effects of HTT with various durations on chlorophyll maintenance during storage were examined (Fig. 2). Loss of chlorophyll was retarded in the florets treated for 2 and $3 \mathrm{hr}$ but not for $1 \mathrm{hr}$. This tendency was similar to changes of organoleptic color score as shown in Fig. 1-B.

The effect of HTT with various durations on carbon dioxide (Fig. 3) and ethylene (Fig. 4) production during storage was examined. Carbon

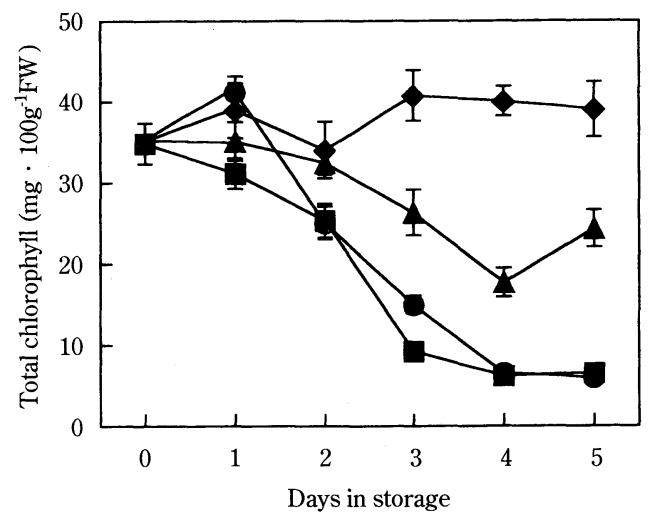

Fig. 2 Changes in total chlorophyll content of broccoli florets during storage at $20^{\circ} \mathrm{C}$ The broccoli heads were treated at $50^{\circ} \mathrm{C}$ for $0(\mathbf{\square}), 1(\mathbf{O})$, $2(\boldsymbol{\Delta})$ or $3 \mathrm{hr}(\boldsymbol{)})$, and subsequently, packed in perforated polyethylene bags and stored at $20^{\circ} \mathrm{C}$. 


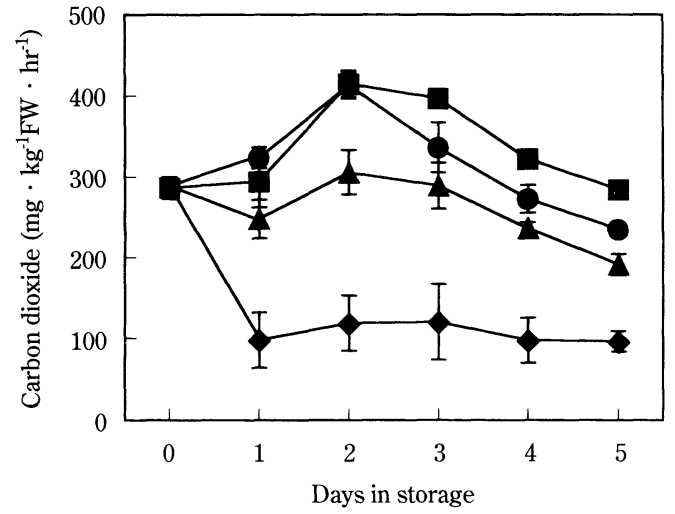

Fig. 3 Changes in carbon dioxide production by broccoli florets during storage at $20^{\circ} \mathrm{C}$ The broccoli heads were treated at $50^{\circ} \mathrm{C}$ for 0 $2(\boldsymbol{\Delta})$ or $3 \mathrm{hr}(\boldsymbol{)})$, and subsequently, packed in perforated polyethylene bags and stored at $20^{\circ} \mathrm{C}$.

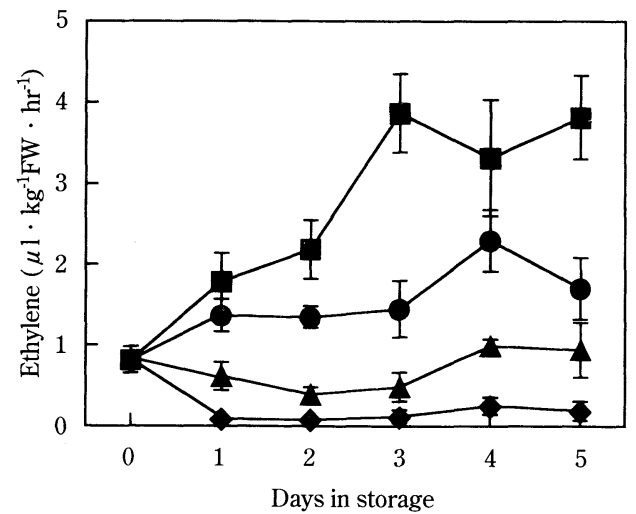

Fig. 4 Changes in ethylene production by broccoli florets during storage at $20^{\circ} \mathrm{C}$

The broccoli heads were treated at $50^{\circ} \mathrm{C}$ for 0

$2(\boldsymbol{\Delta})$ or $3 \mathrm{hr}(\boldsymbol{)})$, and subsequently, packed in perforated polyethylene bags and stored at $20^{\circ} \mathrm{C}$.

dioxide production was inhibited with the duration of HTT, and increased from day 1 to day 2 of the storage and subsequently decreased, however, in the florets of the $3 \mathrm{hr}$ treatment remained at a constant level after day 1 of storage. The ethylene production was reduced at a higher extent compared with carbon dioxide production as the duration of HTT increased. The increases of ethylene production during storage were retarded in the florets with 1 and $2 \mathrm{hr}$ treatments compared with the control, and those with $3 \mathrm{hr}$ treatment scarcely produced ethylene. Previously, TERAI et al. ${ }^{199}$ reported that broccoli florets showed increased carbon dioxide and ethylene production like a climacteric rise during storage at $20^{\circ} \mathrm{C}$. In the present experiment, it was indicated that in broccoli florets, increases in carbon dioxide and ethylene production were inhibited by HTT at $50^{\circ} \mathrm{C}$ for 1 to $3 \mathrm{hr}$ prior to storage, the inhibition being greater in ethylene production than carbon dioxide production.

To specify the point in the ethylene biosynthetic pathway largely affected by HTT, changes in ACC content (Fig. 5) and ACC oxidase activity (Fig. 6) were monitored during storage at $20^{\circ} \mathrm{C}$ after HTT with various durations. ACC content of the control and 1 and $2 \mathrm{hr}$ treated florets increased gradually during storage, with little difference among the three samples. The ACC content in the florets with $3 \mathrm{hr}$ treatment showed a lower level than the others, and subsequently increased slowly. ACC oxidase activity increased rapidly in control and $1 \mathrm{hr}$ treated samples and reached a maxima on day 2 of storage followed by decreases, while the increase of the activity in the florets with $2 \mathrm{hr}$ treatment was retarded and the maximum level was reduced compared with the control and $1 \mathrm{hr}$ treated samples. The florets treated for $3 \mathrm{hr}$ showed little activity. A comparison of ACC

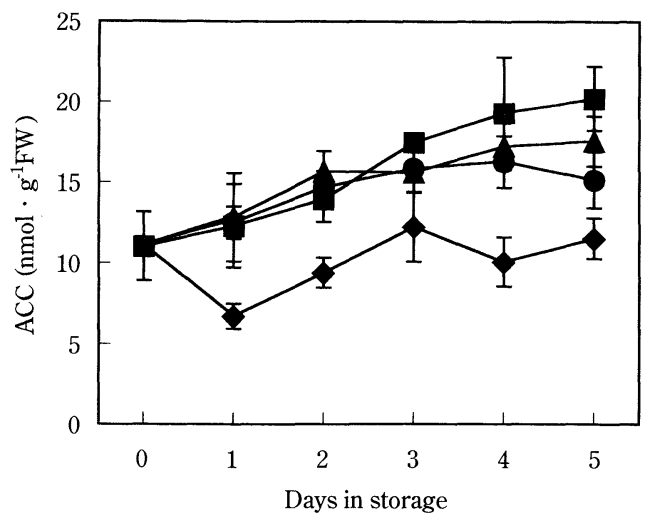

Fig. 5 Changes in ACC content of broccoli florets during storage at $20^{\circ} \mathrm{C}$

The broccoli heads were treated at $50^{\circ} \mathrm{C}$ for 0

$2(\boldsymbol{\Delta})$ or $3 \mathrm{hr}(\boldsymbol{\bullet})$, and subsequently, packed in perforated polyethylene bags and stored at $20^{\circ} \mathrm{C}$. 


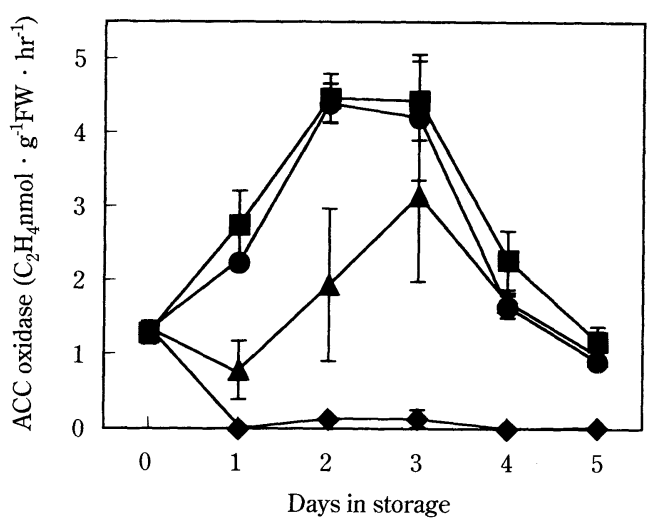

Fig. 6 Changes in ACC oxidase activity of broccoli florets during storage at $20{ }^{\circ} \mathrm{C}$

The broccoli heads were treated at $50^{\circ} \mathrm{C}$ for 0

$2(\boldsymbol{\Delta})$ or $3 \mathrm{hr}(\boldsymbol{\bullet})$, and subsequently, packed in perforated polyethylene bags and stored at $20^{\circ} \mathrm{C}$.

content (Fig. 5) with ACC oxidase activity (Fig. 6) indicates that the florets with $2 \mathrm{hr}$ treatment hardly differed from the control in ACC content but showed a marked difference in ACC oxidase activity, and in the florets with $3 \mathrm{hr}$ treatment, the ACC content increased gradually after day 1 but the ACC oxidase hardly showed any activity during storage. From these results, it is assumed that the ACC oxidase would be more vulnerable to HTT than ACC synthesis, and the reduction of ACC oxidase activity by HTT resulted in the inhibition of ethylene production during subsequent storage. $\mathrm{YU}$ et al.$^{20)}$ reported that in apple plugs incubated at 25 to $40{ }^{\circ} \mathrm{C}$, the ACC content increased with an increase of temperature, but the ethylene production reached the maximum at $30^{\circ} \mathrm{C}$ and decreased at 35 and $40^{\circ} \mathrm{C}$. ATTA-ALY 21) also showed that in pink-stage tomato fruit held at 20 to $35^{\circ} \mathrm{C}$, ethylene production continued to decrease as the temperature increased while ACC content sharply increased at $35^{\circ} \mathrm{C}$. Based on these results, they pointed out that the conversion of ACC to ethylene would be largely affected by high temperature.

In our experiment, $\mathrm{ACC}$ oxidase activity in the florets with HTT at $50^{\circ} \mathrm{C}$ for $1 \mathrm{hr}$ did not show a difference compared with the control, however, the ethylene production was reduced. This result may be due to an experimental procedure in which the ACC oxidase was extracted and then its activity was measured in vitro. APELBAUM et al. ${ }^{22}$ ) suggested that a system for converting ACC to ethylene was membrane-associated, and MAYNE and $\mathrm{KENDE}^{23)}$ showed that the enzyme for ethylene forming was localized on the membrane such as tonoplast in the cell and the ethylene biosynthesis depended on membrane integrity. Thus, it was assumed that these membranes suffered at high temperature even for $1 \mathrm{hr}$ and, consequently, exerted some influence on ethylene production.

On the other hand, it is well known that ethylene promotes yellowing of many green plants ${ }^{24}$. KASAI et al ${ }^{25)}$ reported that ethylene production in broccoli florets significantly increased concurrent with a rapid yellowing ascribed to chlorophyll degradation. YAMAUCHI and WATADA ${ }^{26)}$ showed that yellowing of broccoli florets was promoted by a treatment with $10 \mathrm{ppm}$ ethylene. TIAN et al. ${ }^{27)}$ also reported that in broccoli florets exposed to various concentrations of ethylene for $36 \mathrm{hr}$, the color change from green to yellow represented by hue-angle decline was accelerated as the ethylene concentration increased.

These results supported that $\mathrm{HTT}$ at $50^{\circ} \mathrm{C}$ for a short-term period in the present study would inhibit the conversion of ACC to ethylene and reduce ethylene production resulting in the retardation of yellowing in broccoli florets. Furthermore, the enzymes relating to chlorophyll or chloroplast degradation and the receptor site for ethylene-induced response may also be counteracted by high temperature. These factors concerning the retardation of yellowing should be further investigated.

\section{Acknowledgements}

The authors are grateful to Prof. Dr. H. HYODO, Shizuoka University, for helpful advice and suggestion in analysis of ACC oxidase. 


\section{References}

1) OGura, N., NAKAgawa, H. and TAKeHANA, H. : Nippon Nōgeikagaku Kaishi, 49, 189 (1975)

2) Maxie, E.C., Mitchell, F.G., Sommer, N.F., SNyder , R.G. and RAE, H.L. : J. Amer. Soc. Hort. Sci., 99, 344 (1974)

$3)$ Kato, K. and Sato, R. : J. Japan. Soc. Hort. Sci., 44, 89 (1975)

4) Manabe, M. and Tarutani, T. : Nippon Shokuhin kogyo Gakkaishi, 24, 404 (1977)

$5)$ Porritt, S.W. and Lidster, P.D. : J. Amer. Soc. Hort. Sci., 103, 584 (1978)

6) Yoshioka, H., Ueda, Y. and OGata, K. : Nippon Shokuhin kogyo Gakkaishi, 25, 607 (1978)

7) Komiyama, Y., Harakawa, M. and Tsuji, M. : Nippon shokuhin kogyo Gakkaishi, 26, 371 (1979)

8) Tsuji, M., Harakawa, M. and Komiyama, Y. : J. Japan. Soc. Hort. Sci., 52, 469 (1984)

9) Cheng, T.-S., Floros, J.D., Shewfelt, R.L. and Chang, C.J. : J. Plant Physiol., 132, 459 (1988)

10) Kazami, D., Sato, T., Nakagawa, H. and OGura, N. : Nippon Nōgeikagaku Kaishi, 65, 19 (1991)

11) Forney, C.F. : HortScience, 30, 1054 (1995)

12) Tian, M.S., Woolf, A.B., Bowen, J.H. and Ferguson, I.B. : J. Amer. Soc. Hort. Sci., 121, 310 (1996)

13) Tian, M.S., Islam, T., Stevenson, D.G. and IRving, D.E. : J. Amer. Soc. Hort. Sci., 122, 112 (1997)

14) InskeeP, W.P. and Bloom, P.R. : Plant Physiol., 77, 483 (1985)

15) Terai, H. : J. Japan. Soc. Hort. Sci., 61, 805 (1993)

16) LiZADA, M.C.C. and YANG, S.F. : Anal. Biochem., 100, 140 (1979)

17) Ververidis, P. and John, P. : Phytochemistry, 30, 725 (1991)

18) Hyodo, H., Morozumi, S., Kato, C., TANaka, K. and Terai, H. : Acta Hortic., 394, 191 (1995)

19) Terai, H., Tsuchida, H. and Mizuno, M. : $J$. Japan. Soc. Cold Preserva. Food, 19, 191 (1993)
20) YU, Y.-B., ADAMS, D.O. and YANG, S.F. : Plant Physiol., 66, 286 (1980)

21) Atta-Aly, M.A. : Postharvest Biol. Technol., 2, 19 (1992)

22) Apelbaum, A., Burgoon, A.C., Anderson, J.D., Solomos, T. and Lieberman, M. : Plant Physiol., 67, 80 (1981)

23) Mayne, R.G. and Kende, H. : Planta, 167, 159 (1986)

24) KAYS, S.J. : Postharvest physiology of perishable plant products Ch. 6 p. 335 (AVI, New York), (1991)

25) Kasai, Y., Kato, M. and Hyodo, H. : J. Japan. Soc. Hort. Sci., 65, 185 (1996)

26) YAMAUCHI, N. and WATADA, A.E. HortScience, 33, 114 (1998)

27) Tian, M.S., Downs, C.G., Lill R.E. and KING, G.A. : J. Amer. Soc. Hort. Sci., 119, 276 (1994)

\section{高温処理によるブロッコリー小花の黄化と エチレン生成の抑制}

\section{寺井弘文* · 加納麻記 $*$ 水野雅史 ${ }^{*} \cdot$ 土田廣信 ${ }^{*}$ $*$ 神戸大学農学部 \\ （元657-8501 神戸市灘区六甲台町1-1） \\ $* *$ 神戸大学大学院自然科学研究科 \\ （テ657-8501 神戸市灘区六甲台町1-1）}

収穫後のブロッコリ一小花の黄化を遅らせる目的で, $20^{\circ} \mathrm{C}$ 貯蔵に先だって空気中で $45,50,55^{\circ} \mathrm{C}$ の高温処理 が $1 \sim 5$ 時間行われた。 $50^{\circ} \mathrm{C} ， 2$ 時間や 3 時間の高温 処理は緑色や品質保持について，その他の処理区より効 果的であった。 $50^{\circ} \mathrm{C} て ゙ 1 ， 2 ， 3$ 時間処理しその後 $20^{\circ} \mathrm{C}$ で貯蔵したところ，小花のクロロフィルの減少や 炭酸がスおよびエチレンの生成の増加は 1 時間処理のク ロロフィルの例外を除いて抑制された。その抑制の程度 は処理時間の長さに応じて増加した。貯蔵中の1ーアミ ノシクロプロパン-1-カルボン酸 (ACC) の含量につい て，無処理や $50^{\circ} \mathrm{C} 1$ 時間または 2 時間処理の小花では 同程度増加したが，3時間の高温処理はその増加を遅ら せた。貯蔵中のACC酸化酵素の活性は無処理や $50^{\circ} \mathrm{C} 1$ 時間処理て顕著に増加し，2時間処理がそれに続いた。 これらの酵素活性は最大值に到達後すばやく低下した。 しかし， 3 時間の高温処理の小花では，その活性は貯蔵 中ほとんど検出されなかった。これらの結果から， 
$50^{\circ} \mathrm{C}$ の短時間処理は $\mathrm{ACC}$ エチレンへの変換を阻害し 1化を遅らせる要因となったものと考えられた。

てエチレン生成を抑制し，それがブロッコリ一小花の黄

(平成11年 1 月 21 日受付，平成11年 7 月 19 日受理) 